\title{
The role of ecosystem services in climate and air quality in urban areas: Evaluating carbon sequestration and air pollution removal by street and park trees in Szeged (Hungary)
}

\author{
Márton KISS a , Ágnes TAKÁCS a, Réka POGÁCSÁS a, Ágnes GULYÁS a
}

\begin{abstract}
The evaluation of ecosystem services can provide essential help in incorporatating the multifunctionality of urban ecosystems in planning and management processes. Two important regulating services of urban trees, carbon sequestration and air pollution removal, are evaluated in this article for different types of tree stands (streets, parks) in the city centre of Szeged (Hungary). The necessary calculations were carried out by an adaptation of the targeted model (i-Tree Eco), based on a large complete tree inventory dataset. The analyses revealed the main tendencies in differences between tree species considering the tree condition, which affects the service-providing capacity to a high degree. The effects of differences in tree management on the chosen ecosystem services were investigated by comparing two pairs of tree alleys. Based on our observations, clear cuts and complete tree alley changes are not advisable from an ecosystem service point of view.
\end{abstract}

Keywords: urban ecosystem services, carbon sequestration, air pollution removal, Szeged, Hungary

\section{Introduction}

The rapid growth of urban populations and global climate change call for the elaboration and evaluation of different adaptation and mitigation strategies in these antropogenically-modified climatic circumstances. Among these strategies, one of the most important is the planting and maintenance of trees and other green spaces. On the one hand, vegetation is directly effective through shading and evapotranspiration, improving the quality of life of the resident population by decreasing heat stress. Several investigations have been carried out on such issues at micro- and local scales, based on field measurements, models or remotely-sensed data (Cao et al., 2010; Lee et al., 2013; Lehmann et al., 2014). On the other hand, urban tree stands modify the city's climatic characteristics and air quality by the sequestration of carbon dioxide and the removal of various air pollutants, and by reducing stormwater runoff (Jim and Chen, 2008; Kirnbauer et al., 2013; Nowak et al., 2013). Furthermore, trees in particular are considered to have significant aesthetic and eco-psychological values (O'Campo et al., 2009; Tyrväinen et al., 2003). Studies have been carried out also to express the monetary value of these effects, using the methodologies of hedonic pricing (Donovan and Butry, 2011; Sander et al., 2010), choice experiments (Giergiczny and Kronenberg, 2014) and travel costs (Teknomo, 2005).

The multifunctionality of urban ecosystems is a wellknown fact (Haase et al., 2014), and a methodology for the evaluation of ecosystem sevices could play an important role in its promotion and its incorporation into decision-making processes. The essence of this approach, originating primarily from the fields of landscape ecology and ecological economics, is to quantify those goods and services of ecosystem and landscape elements that contribute directly or indirectly to human well-being (Bolund and Hunhammar, 1999; GómezBaggethun and Barton, 2013; Gómez-Baggethun et al., 2013). Due to the integrated approach and monetary quantification (which can be carried out for some of the services), this methodology could play an important role in furthering the interests of nature conservation. This is indicated by several significant international policy documents, and the foundation of IPBES (Intergovernmental Platform on Biodiversity and Ecosystem Services: MEA, 2005; Perrings et al., 2011; TEEB, 2010a,b).

The evaluation of climate- and air quality-related ecosystem services of urban trees is an important task. As an example, heat stress mitigation is a service which is perceived directly by inhabitants, and it has a strong effect on the use of urban public spaces (Égerházi et al., 2013). As well, the significance of the service of air pollution removal is highlighted by the fact that changes in air pollutant concentrations can be quantitatively related to the occurence of some diseases and to mortality rates, which means that this service is directly contributing to human well-being (Nowak et al., 2014).

These evaluations can be carried out relatively easily using allometric and growth equations of different tree species (based on data from forestry practice). Using such findings, several targetted models have been developed using these data to calculate some of these services, mainly carbon sequestration and air pollution removal, completed sometimes with monetary evaluations (i-Tree, 2014; Peng et al., 2008). These have been used in many cities in the world, and sometimes they are an integral part of the official urban tree management processes (City of Melbourne, 2012; Rogers et al., 2011). At this point in time,

\footnotetext{
${ }^{a}$ University of Szeged, Department of Climatology and Landscape Ecology, Szeged, Hungary (*corresponding author: M. Kiss, e-mail: Kiss.Marton@geo.u-szeged.hu)
} 
however, we are not aware of any studies published on assessments of climate- and air quality-related ecosystem services, based on large tree inventories from the wider region of Central Eastern Europe.

As described above, urban trees can alter the climatic conditions of cities considerably, even though, as a reverse effect, the built environment and anthropogenic heat surplus create a special environment for the trees. A weaker tolerance to urban circumstances may result in worse (less healthy) tree conditions in the case of certain species, which can be observed from the referring tree attributes in the field, or can be calculated by models. In the case of worse tree conditions, the trees provide less services.

Besides the main vegetation type and species characteristics, the services provided by certain ecosystems are influenced strongly by land management intensity. The evaluation and modelling of these effects are in the focus of recent ecosystem service research (Petz and van Oudenhoven, 2012). This approach is becoming more important in the case of urban tree stands as well. Some of the important management-related questions are: How long should the rotation cycle be in the case of urban tree stands? What kind of tree maintenance works should be used to keep the trees' service-providing capacity as high as possible? There are some published results aimed at the comparison of different-aged, differently-managed tree stands, mainly from the U.S. (Martin et al., 2012; McPherson, 2003; McPherson and Kendall, 2014). To date, however, we have rather few empirical studies on the effects of different species selection policies and treatment practices from the point of view of ecosystem services. Using the methodology proposed in this study, we can express some of the important regulating services in monetary value, which can facilitate their incorporation into urban planning and management.

As a result of these research needs, we provide and discuss the results of an individual-based ecosystem service assessment, based on a complete tree inventory. The analyses refer to tree stands in the centre of Szeged (Hungary). Our first goal was to investigate the significance of the urban trees from the point of view of two services, carbon sequestration and air pollution removal, given the Central European climatic circumstances. This was achieved with the adaptation of a targetted model (i-Tree Eco). Another goal was to assess the service-providing capacity of different species, with relation to their general condition. This also needed the complete inventory, where data representing stands of different species were available for comparison. The significance of protected trees compared with other stands in terms of ecosystem services, is an important issue in the green space management of the city. Some preliminary empirical results are presented, from a case study using differently managed tree alleys, which are nonetheless situated in similar built environments and which are originally of about the same age.

\section{Data and methods}

\subsection{Study area}

The general study area was located in the centre of Szeged, situated in South-East Hungary. The city is characterized by a dry-warm continental climate. Szeged is the administrative centre of Csongrád county, with ca. 170,000 inhabitants. Because of its size, the urban heat island effect and air pollution are considerable, and these have been studied in detail in previous research (Kántor et al., 2012; Makra, 2005; Unger et al., 2014). The structure of the city is characterized by radial avenues and three boulevards. The downtown area, which is located inside the innermost boulevard, constituted the main area for this investigation.

The entire investigated stand (i.e., total urban forest) is composed of 2,846 trees, situated mainly in tree lines, while the rest are park stands on squares. About one-third of the trees are protected (by local regulation of the municipality). An important element of legal protection, from the point of view of our analysis, is that in protected tree alleys clearcuts are prohibited, trees can be cut down and substituted only inidvidually, due to 'bad' condition or for safety reasons. The differences between protected and non-protected stands are

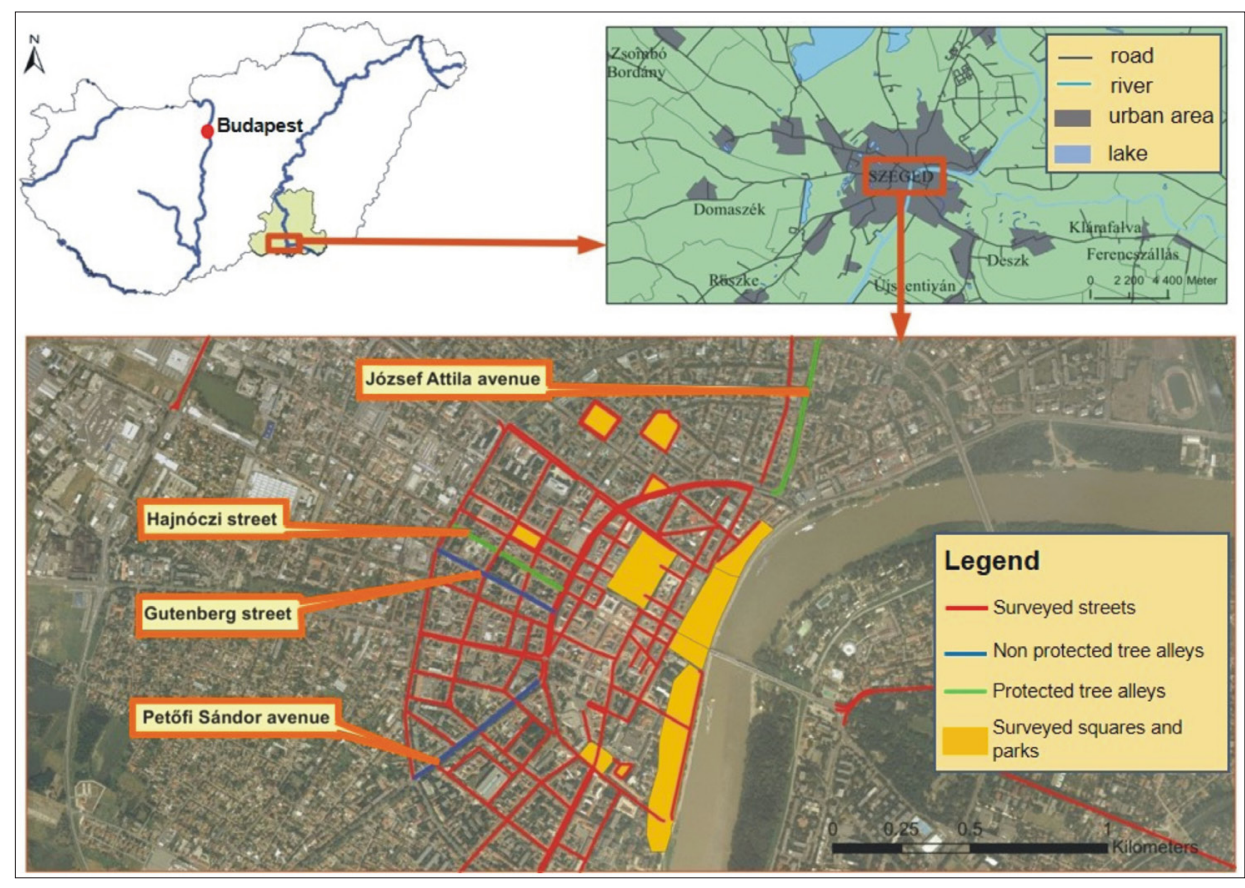

Fig. 1: The surveyed streets and squares, and the four case study areas in Szeged (Hungary)

Source: author's elaboration 
primarily due to age differences. Therefore, to evaluate some of the effects of management differences, we chose stands which are of about the same age originally, situated in similar urban morphological zones that represent the characteristic built environments of the downtown of Szeged, and which are 'special' from a management aspect.

The tree alleys of boulevards and avenues are very important elements of the townscape and of the green infrastructure as well. One of them (József Attila avenue) is protected in its full length, and this was the main reason that it could be preserved in an almost completely undisturbed form during a large infrastructure development project in the 2000s (Szentistványi, pers. comm.). In contrast, in the tree alley of the Petőfi Sándor avenue (which is situated in a similar environment to the József Attila avenue, and is approximately the same age), large parts of the tree crowns and a considerable number of whole trees were cut down. The protected Sophora japonica tree alley of the Hajnóczi street is situated in a central part of the city centre (mostly under heritage protection). In the parallel Gutenberg street, a very similar Sophora japonica tree alley (of the same age, but without legal protection) was cut down entirely and substituted with a young Tilia tomentosa tree line.

\subsection{Data and materials}

The analyses are based on a field-based complete tree inventory, that had been produced in the vegetation period of 2012 and 2013, with the strong cooperation of the municipal public utility company responsible for green space management. The exact locations of the trees were available from a baseline GIS database of the city, which considerably aided the field survey. For the latter, we applied the protocol of the i-Tree model (i-Tree, 2014). We recorded the attributes of every street and park trees in the study area, if its diameter at breast height $(\mathrm{DBH})$ exceeded $5 \mathrm{~cm}$. The height of the tree, the height to base of live crown and the crown diameter were measured using the Vertex III ultrasonic hypsometer. The diameter was recorded at $1.37 \mathrm{~m}$ (breast height), under which, in case of multi-stemmed individuals, every stem was measured which exceeded $5 \mathrm{~cm}$ in DBH. The ratio of canopy missing and ratio of branch dieback in crown data are used to rate tree condition and to adjust downward leaf area and biomass data, which are calculated with the help of allometric equations (Nowak et al., 2008). The percent of canopy missing and dieback data were recorded in 5-percent intervals in the field. The growth of a certain individual is corrected with the crown light exposure (CLE) data (number of sides of the tree receiving sunlight - maximum of five). The data collected in the field were primarily imported and stored in "Greenformatic" software, which was developed in Hungary specifically for urban tree registers and which is capable of storing i-Tree datasets. From Greenformatic, we exported the data into MS Access format, which is the required format of the applied model.

\subsection{The i-Tree Eco model}

The elements of the i-Tree software suite are tools used world-wide for calculating climate- and air quality-related ecosystem services of urban trees. From the tools of the i-Tree (formerly UFORE - Urban Forest Effects Model) suite (i-Tree Eco, Streets, Hydro, Design), Eco is the most suitable for international use. The model calculations are based on well-defined allometric relationships between indicators of the relevant ecosystem services (amount of biomass, leaf area) and measured size parameters of the trees. The first part of the model results cover the most important structural characteristics of the urban forest (leaf area, canopy cover, tree condition, etc.). The tree condition categories are given based on the proportion of branch dieback in crown data (excellent: < 1\%, good: $1-10 \%$, fair: $11-25 \%$, poor: $26-50 \%$, critical:51-75\%, dying: 76-99\%).

The second main part of the results include the estimates on the investigated ecosystem services. Carbon storage is quantified with the help of the above-mentioned allometric equations. Annual growth (from which annual carbon sequestration is calculated) estimates are based primarily on standardized growth rates (that take into account climatic characteristics of the study area), which are adjusted based on tree condition and crown light exposure data (which represent forest or open-growth conditions). The air pollution removal (dry deposition) calculations are carried out using pollutant concentration datasets of the study area, by calculating deposition velocities, for which detailed meteorological datasets are needed from the study site.

The i-Tree model has to be adapted for use outside the U.S. It needs the integration of some basic geographical data, information on the growth characteristics of the tree species specific to the study area, and local meteorological and air pollutant datasets. As all of the species in our inventory can be found in the i-Tree Eco species database (partly because of their American origin), no additional species information was needed. The general climatic characteristics of the area (e.g., number of frost-free days) affect the annual growth rates, while meteorological data with high temporal resolution is needed for the calculation of deposition velocities of pollutants. The meteorological datasets employed here are from the meteorological station of Szeged (run by the Hungarian Meteorological Service). Air pollution removal was calculated for $\mathrm{CO}, \mathrm{NO}_{2}, \mathrm{PM} 10$, $\mathrm{SO}_{2}$ and $\mathrm{O}_{3}$, their hourly concentration datasets were provided by the local station of the Hungarian National Air Quality Network. After compiling and properly formatting the above-mentioned datasets (together with the tree inventory), the data processing was carried out by the US Forest Service. The model was implemented for the year 2012 (meteorological and air pollution datasets for 2012 were used). The monetary value of carbon sequestration was calculated based on the marginal social cost of carbon data (Tol, 2008), while that of air pollution removal was estimated using country-specific median externality values (PowerConsult, 2010). As these values could be found only for earlier years, the values were converted to the study year using Producer Price Indices of the subsequent years (ÁKK, 2014).

\section{Results}

In this section, the characteristics of the forest structure are described, followed by the results for the two investigated services. The total tree stand is described mainly with respect to the share of different species, while the comparison of stands with management differences is carried out partly with DBH categorisation.

\subsection{Forest structure}

\subsubsection{Structural characteristics of the total tree stand}

The total urban forest of the city is characterised by high species diversity: exactly 100 species can be found in this area, slightly larger than $2 \mathrm{~km}^{2}$. Some of them, about one-half (48\%), are native in Hungary. The major elements of the urban forest consist of street tree lines, but the tree 
populations in parks are also planted stands. The ten most common species amount to $70 \%$ of the whole urban forest (1,992 individuals, Tab. 1.), and most of our analyses of the total tree stand are related to the characterization and comparison of the populations of these species.

For most species, there is a dominant size range (which can be described with the standard deviation of $\mathrm{DBH}$, Tab. 1). This shows that in recent years, different species were preferred when planting tree lines. More than half of the species (53) have less than 10 individuals, these were planted partly when diverse parks were created or if individuals of formerly homogeneous tree alleys were substituted with new species.

Leaf area is one of the most important state indicators of the investigated ecosystem services, therefore examining the weight of different species within the total population is necessary (Fig. 2). The Platanus hybrida stand is outsanding in leaf area (37.7\% share in the total leaf area), followed by the populations of Celtis occidentalis (10.1\%) and Sophora japonica (9.1\%). The order from the point of view of the species' share in the number of trees is slightly different (Platanus hybrida is first with $10.7 \%$, the second is Tilia cordata (10.4\%), third is Sophora japonica (9.7\%) and Celtis occidentalis was ranked only the fourth (8.9\%)). The population of Tilia tomentosa has very small amount of leaf area, compared to its share in the number of individuals.

The health condition of the populations of different species might be a factor that affects the amount of leaf area to a strong degree. It can be said that the total studied stand is considerably "good" in terms of its condition, as most of the individuals were classified into "excellent" or "good" categories (Fig. 3). This is partly a consequence of the design of the model, but proper management also plays a significant role (trees in very bad health status are replaced relatively quickly). Large differences between species, however, can also be observed from the point of view of tree condition, which highly influences the amount of provided services. For example, the populations of Platanus hybrida and Acer platanoides are in a good general condition (only 14.7\% and $19.5 \%$ of their individuals are in worse (fair or worse) tree condition). The same situation applies to Tilia tomentosa and Fraxinus ornus stands (60.9\% of the individuals are in "excellent" condition in both populations). In contrast, considerable parts of the populations of two native Tilia species (Tilia cordata, Tilia platyphyllos) are ranked as 'worse' health categories (27.4\% and $24.8 \%$ ), and similar observations can be made of the individuals of the Sophora japonica population (19\% and $31.2 \%$ ).

\subsubsection{Structural attributes of the stands with different management regimes}

To evaluate the characteristics of ecosystem services provided by different stands, it is necessary to investigate their main structural characteristics, in a similar fashion to the total urban forest. We provide summarized data for these stands in Table 2.

The tree alley of the József Attila avenue has the largest trees among the four subsamples chosen for this case study, with an average DBH of $43.7 \mathrm{~cm}$, higher than the same value of the total urban forest. From the investigated stands, it has the largest leaf area, even if there are more trees on Petoffi avenue. The values of $3.6 \%$ (dieback) and $10.8 \%$ (canopy

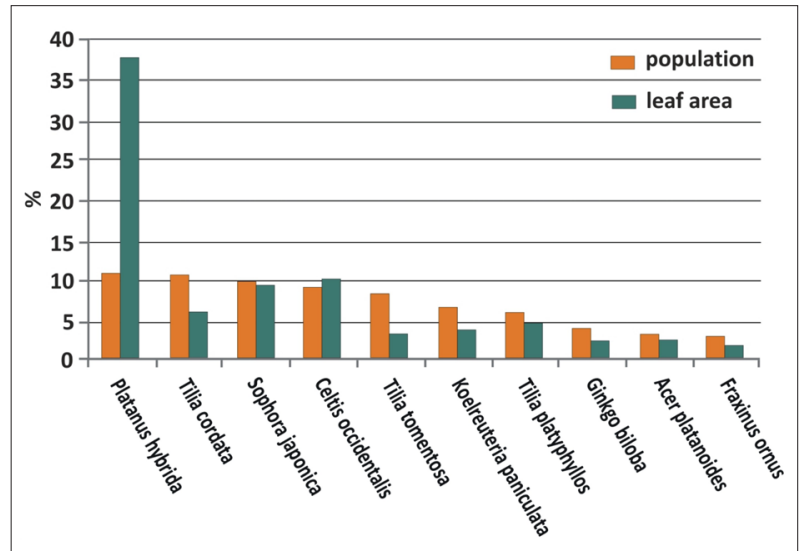

Fig. 2: Percentage of the ten most common species and their share in the whole leaf area

Source: author's calculations

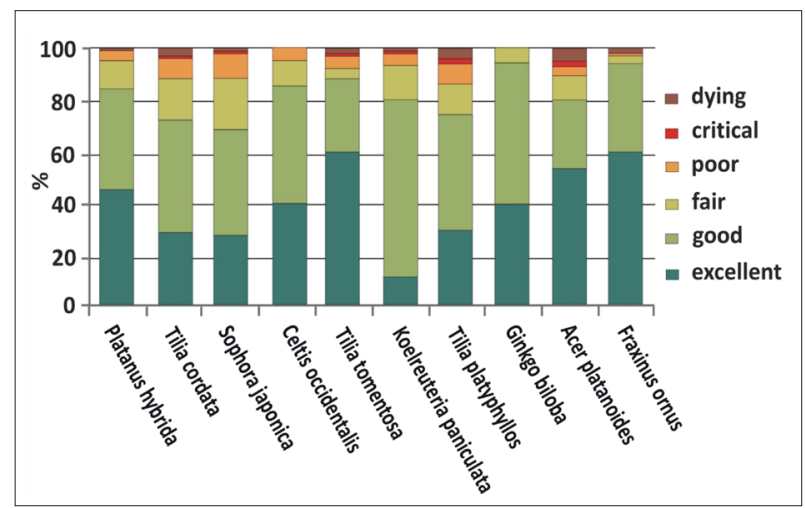

Fig. 3: Tree conditions in the populations of the ten most common species. Source: author's calculations

\begin{tabular}{|l|c|c|c|c|c|}
\hline \multicolumn{1}{|c|}{ Species } & Number of trees & Canopy cover $\left.\mathbf{( m}^{\mathbf{2}}\right)$ & Leaf area $\left.\mathbf{( m}^{\mathbf{2}}\right)$ & Avg. DBH $(\mathbf{c m})$ & Std. dev. of DBH \\
\hline Platanus hybrida & 305 & $58,697.4$ & $229,455.5$ & 63.0 & 25.2 \\
\hline Tilia cordata & 295 & $8,080.0$ & $36,249.4$ & 28.4 & 16.7 \\
\hline Sophora japonica & 276 & $23,635.1$ & $55,252.7$ & 47.5 & 18.6 \\
\hline Celtis occidentalis & 252 & $16,210.4$ & $61,215.2$ & 36.2 & 17.5 \\
\hline Tilia tomentosa & 235 & $4,375.1$ & $19,355.9$ & 18.0 & 14.1 \\
\hline Koelreuteria paniculata & 184 & $8,097.5$ & $21,567.1$ & 29.4 & 9.7 \\
\hline Tilia platyphyllos & 165 & $7,119.1$ & $27,978.8$ & 28.2 & 13.9 \\
\hline Ginkgo biloba & 111 & $5,164.1$ & $14,737.5$ & 33.2 & 16.8 \\
\hline Acer platanoides & 87 & $3,014.9$ & $13,547.9$ & 20.3 & 13.9 \\
\hline Fraxinus ornus & 82 & $3,216.1$ & $9,807.0$ & 22.1 & 11.9 \\
\hline
\end{tabular}

Tab. 1: Characteristics of the ten most abundant species in the urban forest of Szeged. Source: author's calculations 


\begin{tabular}{|l|c|c|c|c|c|}
\hline & $\begin{array}{c}\text { Average DBH } \\
(\mathbf{c m})\end{array}$ & $\begin{array}{c}\text { Total leaf area } \\
\left(\mathbf{m}^{\mathbf{2}}\right)\end{array}$ & $\begin{array}{c}\text { Average percent of } \\
\text { missing crown (\%) }\end{array}$ & $\begin{array}{c}\text { Average percent of } \\
\text { crown dieback (\%) }\end{array}$ & Number of trees \\
\hline József A. avenue & 43.7 & $39,805.5$ & 10.8 & 3.6 & 103 \\
\hline Petőfi S. avenue & 33.8 & $14,374.2$ & 34.3 & 23.5 & 123 \\
\hline Hajnóczi street & 31.4 & $8,033.2$ & 36.2 & 16.0 & 95 \\
\hline Gutenberg street & 8.1 & 666.3 & 1.6 & 0.5 & 110 \\
\hline
\end{tabular}

Tab. 2. Structural characteristics of investigated stands with different management regimes Source: author's calculations

missing) are much lower than the city averages (8.4\% and $17.9 \%$ ). Due to protection and homogeneous management, the József Attila tree alley consists of only four species (with dominance of Platanus hybrida and Quercus robur "Fastigiata").

The alley of Petőfi Sándor avenue boasts the highest number of trees. During transportation development works, some individuals of the non-protected original tree line of Tilia tomentosa (which was approximately the same age as the József Attila alley and was in a good condition originally) were cut down. In the locations of the cut Tilia trees, trees of several species were planted (there are 15 species now). The average percent of missing crown (34.3\%) and crown dieback (23.5\%) are well above the total urban forest averages.

Hajnóczi street is a characteristic, quite narrow street, bordered by 2-3-storey buildings. Despite the small area, the tree alley consists of quite large individuals, most of which are Sophora japonica trees (77 trees). The amount of leaf area is considerably low, compared to the realatively high average DBH of the individuals. This is connected to the fact that the average percent of missing crown value is extremely high $(34.3 \%)$, and the average crown dieback (23.5\%) is also much higher than the total urban forest average.

Gutenberg street is the neighbouring street, with similar neighbouring buildings and a "building height:street width" ratio. There was a tree alley like the one on Hajnóczi street, which was cut down and substituted with an almost homogeneous young Tilia tomentosa tree line. The young individuals are in 'good' condition, with low values of percent of missing crown and dieback.

\subsection{Ecosystem service provision}

\subsubsection{Carbon sequestration and air pollution removal in the total tree stand}

Differences between species in carbon sequestration and storage capacity are mainly determined by the differences in size distribution. The Platanus hybrida population can be characterized by an extremely high annual sequestration, which can reach $60 \mathrm{~kg} /$ year or even more for the largest individuals. The 305 Platanus hybrida trees store 428.9 tons of carbon, which is more than one third of the total stored carbon (1,169 t) of the studied urban forest. Sophora japonica have the second largest annual carbon sequestration values (23.5 kg/tree on average), and the third is Celtis occidentalis (15.8 t/yr). The economic value of carbon sequestration per tree is between $0.1-0.2 € / \mathrm{yr}$ for most species, but the values of the species with highest sequestration rates are above that. The total carbon sequestration of the whole studied urban forest amounted to $720 € / \mathrm{yr}$ in economic value. The order of the species based on carbon storage, is obviously mostly parallel with the one based on the leaf area (both

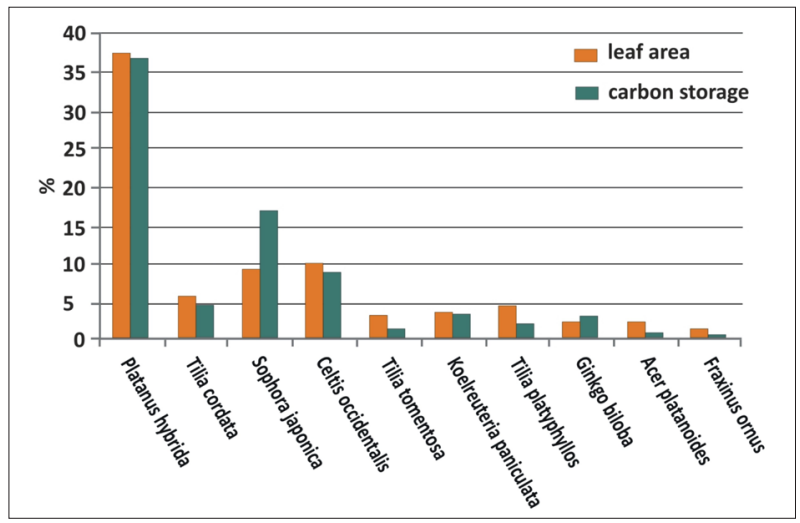

Fig. 4: The share of the ten most common species in the whole leaf area and in the amount of stored carbon Source: author's calculations

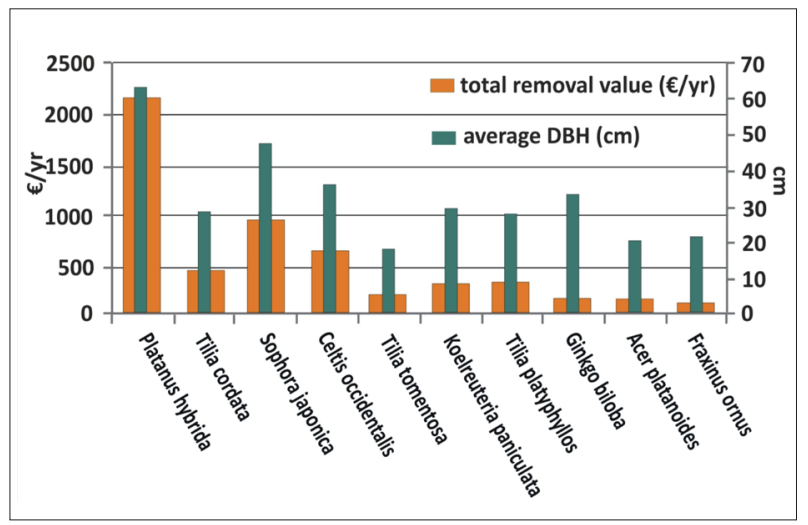

Fig. 5: Total monetary value of air pollution and average diameter at breast height $(\mathrm{DBH})$ for the ten most common species.

Source: author's calculations

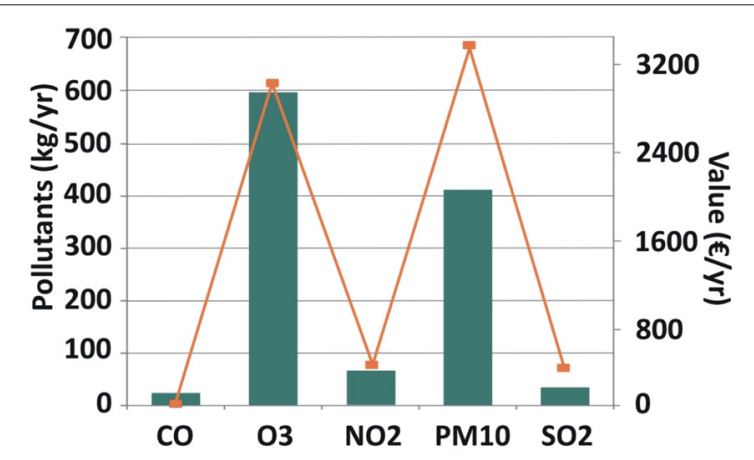

- Pollutants removed -- Value of pollution removal

Fig. 6: Total amounts of removed pollutants $\left(\mathrm{CO}, \mathrm{O}_{3}\right.$, $\mathrm{NO}_{2}, \mathrm{PM}_{10}, \mathrm{SO}_{2}$ ) and their economic value

Source: author's calculations 
have strong connection with primary production). In some cases, however, slight differences can be detected which may indicate the health status of the species. For instance, the Sophora japonica population clearly has a relatively small leaf area compared to its carbon storage capacity (Fig. 4).

The differences in air pollution removal between species and its relation to the average diameter at breast height are basically parallel with the previously-described leaf area carbon storage relations (Fig. 5), as leaf area is the ecosystem indicator with respect to the quantification of the service. The average removal per tree (calculated by summarizing the values of all of the pollutants) ranges between $200-400 \mathrm{~g} / \mathrm{yr}$ for most species (1-2€/yr in monetary value); this is outweighed only by Platanus hybrida (1059.1 g/yr; $6.9 € / \mathrm{yr})$ and Sophora japonica $(556.8 \mathrm{~g} / \mathrm{yr} ; 3.4 € / \mathrm{yr})$.

If we examine the different pollutants separately, it is clear that the highest amounts are removed (with the highest economic values) from those pollutants that have the highest concentrations in the city in general. In the investigated urban forest in Szeged, where there are no considerable industrial emissions, the highest removal values can be observed in the case of $\mathrm{O}_{3}(\sim 600,000 \mathrm{~g} / \mathrm{yr}$ in total $)$ and PM10 $(\sim 400,000 \mathrm{~g} / \mathrm{yr})$, which are mainly from traffic (Fig. 6).

In the concentrations of the latter, dust coming from the neighbouring landscapes as a result of wind erosion may also have a significant role (Szatmári, 2005). The total economic value of air pollutant removal was 7,127 € for 2012 , which is quite high, almost ten times the amount of the economic value of carbon sequestration.

\subsubsection{Comparison of service provision by the investigated stands}

The amount of the two provided services and their economic value for the four places can be seen in Tab. 3 . The compared street and avenue pairs are similar in the number of trees, but, due partly to management-related interventions, they are different in size distribution. Therefore, the comparisons of the stands are more informative with categorisation based on DBH (Martin et al., 2012).

In the smallest diameter class $(1-15 \mathrm{~cm})$, the József Attila stand, and in the largest diameter class $(>76 \mathrm{~cm})$, both avenues have such a small amount of trees (below 10), which make comparisons impossible. In the case of carbon storage and sequestration, the average values of József Attila avenue are higher in every diameter classes, and in the economic values as well. The relations are mainly the same in the case of air pollution removal. In the smallest diameter class that was considered, however, in spite of the higher percentages of average canopy missing and dieback of the trees in the József Attila avenue, air pollution removal appeared to be much lower than that of the trees in the same diameter class in Petőfi Sándor avenue. In the other diameter classes, clearly larger carbon sequestration and air pollution removal values can be observed for the trees of József Attila avenue. The differences in economic value of the two services can reach $2-5 €$ /year per tree.

The tree alleys of the two smaller streets are not suitable for this kind of comparison, as the population of the Gutenberg street belongs to only one diameter class.

\begin{tabular}{|c|c|c|c|c|c|}
\hline DBH (cm) & $\begin{array}{c}\text { Average carbon } \\
\text { storage per tree } \\
(\mathbf{k g})\end{array}$ & $\begin{array}{l}\text { Average carbon } \\
\text { sequestration per } \\
\text { tree }(\mathbf{k g} / \mathbf{y r})\end{array}$ & $\begin{array}{c}\text { Average value of } \\
\text { carbon sequestration } \\
\text { per tree }(€ / \text { yr })\end{array}$ & $\begin{array}{c}\text { Average } \\
\text { removal amount } \\
(\mathrm{g} / \mathbf{y r})\end{array}$ & $\begin{array}{c}\text { Average removal } \\
\text { value per tree } \\
(€ / \mathbf{y r})\end{array}$ \\
\hline \multicolumn{6}{|c|}{ József Attila avenue } \\
\hline $1-15$ & 22.4 & 4.4 & 0.1 & 44.4 & 0.2 \\
\hline $16-30$ & 130.6 & 11.3 & 0.2 & 105.5 & 0.3 \\
\hline $31-45$ & 335.8 & 17.9 & 0.3 & 241.5 & 0.7 \\
\hline $46-60$ & 810.7 & 28.3 & 0.5 & 877.7 & 3.7 \\
\hline $61-75$ & $1,380.1$ & 41.4 & 0.7 & $1,350.6$ & 5.7 \\
\hline $61-76$ & $1,269.1$ & 39.3 & 0.7 & $1,540.8$ & 6.5 \\
\hline $76+$ & $2,092.1$ & 56.7 & 1.0 & $1,490.3$ & 6.2 \\
\hline \multicolumn{6}{|c|}{ Petőfi Sándor avenue } \\
\hline $1-15$ & 13.2 & 2.6 & 0.01 & 151.3 & 0.5 \\
\hline $16-30$ & 81.9 & 6.7 & 0.1 & 171.1 & 0.6 \\
\hline $31-45$ & 237.5 & 9.5 & 0.2 & 248.7 & 0.9 \\
\hline $46-60$ & 512.3 & 16.0 & 0.3 & 414.4 & 1.5 \\
\hline $61-75$ & 971.0 & 23.9 & 0.4 & 260.9 & 0.9 \\
\hline $61-76$ & 675.8 & 21.7 & 0.4 & 145.2 & 0.5 \\
\hline $76+$ & $1,450.9$ & 32.8 & 0.6 & 402.6 & 1.5 \\
\hline \multicolumn{6}{|c|}{ Hajnóczi street } \\
\hline $1-15$ & 23.9 & 3.9 & 0.1 & 80.4 & 0.3 \\
\hline $16-30$ & 134.8 & 10.2 & 0.2 & 170.5 & 0.6 \\
\hline $31-45$ & 340.1 & 16.3 & 0.3 & 256.8 & 0.9 \\
\hline $46-60$ & 723.8 & 24.3 & 0.4 & 669.3 & 2.0 \\
\hline \multicolumn{6}{|c|}{ Gutenberg street } \\
\hline $1-15$ & 5.7 & 1.7 & 0.01 & 8.5 & 0.0 \\
\hline
\end{tabular}

Tab. 3: Ecosystem services provided by the investigated stands, by diameter class (cm). Source: author's calculations 
In fact, the comparison of these two streets rather mean the quantification of the effects of the tree removal on ecosystem services (see, e.g. Pothier and Millward, 2013). The total amount of stored carbon in the trees of Hajnóczi street is $24,520.4 \mathrm{~kg}$, while the same data for the Gutenberg street (total stored carbon in the small Tilia tomentosa trees) is $629.4 \mathrm{~kg}$. The average annual carbon sequestration is $13.2 \mathrm{~kg} /$ tree at Hajnóczi street (with an economic value of $0.24 € / \mathrm{yr}$ ), and $1.72 \mathrm{~kg} /$ tree for Gutenberg trees (economic value: $0.03 € / y r)$. Considering air pollution removal, the total annual removal in the case of Gutenberg street was observed to be $936 \mathrm{~g} / \mathrm{yr}$ (with an economic value of $4.8 € / \mathrm{yr}$ ), while in Hajnóczi street it was 22,314.6 g (with an economic value of $73.5 € / \mathrm{yr})$.

\section{Discussion}

The structural characteristics of the urban forest in Szeged are similar in principle to those of other East Central European cities. The share of non-native species recorded as $50 \%$ or even more is typical of other cities as well, where i-Tree analyses were carried out (e.g., Chaparro and Terradas, 2009; Rogers et al., 2011). The American and Asian species, which were introduced as ornamental trees in previous times, are sometimes more urban tolerant than native species. This can be observed in better tree conditions in the analyses and may result in better ecosystem serviceproviding capacity. The consequence of the parallel use of native and non-native species is a very high species diversity within a considerably small area. The species selection in urban areas and the resulting forest structure depend to a strong extent on the ownership characteristics and on the species selection policy of the forest managers.

In the investigated urban forest in Szeged, there is a small number of planting activities by the inhabitants, besides the work of the urban public enterprise which is responsible for urban tree management. Apart from that, the very high tree species diversity in urban, institutional environments appears in the results of other analyses as well (Pothier and Milward, 2013). As a consequence, there is also a high diversity in the services provided, owing to the different growth and leaf area production capacities of the different species. The system of i-Tree can handle this, as allometric equations for hundreds of species that are native in different continents, are stored in the species database of the model. And the modules which are used in this analysis (calculations of urban forest structure, carbon sequestration and air pollution removal) are suitable for use outside the U.S. in different climatic zones, after proper model adaptation.

The greater or smaller weight of particular species compared to their number of individuals, is a consequence primarily of the size distribution. For instance, the oldest tree alleys of the city, where the oldest trees are present, consist mainly of Platanus hybrida individuals; this is the reason for the very high share of the species in the total leaf area. Meanwhile, a huge part of the Tilia tomentosa population form a newly-planted, homogeneous tree line in the city centre, thus it is represented with hundreds of individuals but with considerably low leaf area. The share of different species in the total leaf area provides information on the performance of the populations from an ecosystem service point of view. The tree condition is calculated automatically by the i-Tree Eco software, and a quite large share of "good" and "excellent" categories was reported in other i-Tree studies as well (Martin et al., 2012). The main reason for this is that this categorisation is based on the percentage of branch crown dieback in the crown data. This may result in better tree condition categories than the trees' real health status, because "poor", "critical" or "dying" categories are given only if the dieback is above $25 \%$. This occurs very rarely, because if there is such a large amount of dead branches and foliage, those parts are cut off by the management company, or if that is the case for several neighbouring trees, the solution is sometimes the complete replacement of the tree alley.

But there are some species-specific differences even with this type of categorisation, which could provide valuable information for species selection. As an example, in the urban forest of the city centre of Szeged, the "worse" condition of two native Tilia species (Tilia cordata, Tilia platyphyllos) was detected, which refers to their lower urban tolerance, and calls attention to the need for further research specific to these trees. The good condition of the Platanus hybrida population contributes to the extremely high amount of leaf area, and it is a popular species planted mainly in tree alleys in Hungary and many countries in Europe. The good tolerance of urban circumstances and the large amount of leaf area provided by these trees is indicated by the fact that more than half of most of the services were connected to this species, in the analysis of Rogers et al. (2012). The good health state of the individuals of Tilia tomentosa indicates the relatively complete canopies in the newly-planted tree line. The adequate general condition of Acer platanoides trees appears also in other studies. In the contribution of Pothier and Millward (2013) on an urban forest analysis in Toronto, the individuals of this species appeared to be the best from the point of view of carbon sequestration and air pollution removal (due partly to the good tree condition of the population). Thus, this species might be considered suitable for urban planting in the climatic circumstances of this study, without regard to nativeness.

From the investigated ecosystem services, the results of carbon sequestration can be compared more easily to the results of other studies, as air pollution removal is calculated based on hourly meteorological data and on pollutant concentrations, which have very strong variability between different cities. The average carbon storage of $410.8 \mathrm{~kg} /$ tree and yearly carbon sequestration of $14.01 \mathrm{~kg} /$ tree (referring to the complete urban forest in Szeged) are close to the results of Wälchli (2012), obtained for Zürich (Switzerland) with i-Tree Eco analysis (348.9 kg and $12.97 \mathrm{~kg} / \mathrm{yr}$ ), and to the results of Russo et al. (2014) for Bolzano (Italy), calculated with allometric equations $(377.4 \mathrm{~kg}$ and $12.1 \mathrm{~kg} /$ $\mathrm{yr})$. In the latter publication, the species composition of the urban forest was quite similar to the one in Szeged. From the main species, the Platanus hybrida population can be characterized with roughly similar size distribution (mean DBH: $64.5 \mathrm{~cm}$ ) to the London planes of Szeged (mean DBH: $63 \mathrm{~cm}$ ). We obtained $1406.2 \mathrm{~kg}$ as the average carbon storage per tree, and $35.9 \mathrm{~kg} / \mathrm{yr}$ as average carbon sequestration per tree for Szeged. These values were slightly above $1,500 \mathrm{~kg}$ and $35 \mathrm{~kg} / \mathrm{yr}$ (allometric equationbased calculations).

We are not aware of published carbon sequestration estimates for DBH classes from European cities. Martin et al. (2012) published results referring to an institutional environment (university campus) for the city of Auburn (Alabama, USA), which is situated in the same wider climatic zone (Köppen's Cfa) as Szeged. From the climatic characteristics, the number of frost-free days is most 
important for the carbon calculations of i-Tree. The carbon sequestration estimates were (in the $\mathrm{DBH}$ categories used in our study as well: $1-15 \mathrm{~cm}, 16-30 \mathrm{~cm}, 31-45 \mathrm{~cm}, 46-60 \mathrm{~cm}$, $61-75 \mathrm{~cm}, 76+\mathrm{cm}): 3,8,15,22,32,54 \mathrm{~kg} / \mathrm{yr}$, respectively. The values for the same categories in the total tree stand of Szeged (in a little colder and drier climate in general) are: $2,7,13,24,36,54 \mathrm{~kg} / \mathrm{yr}$. A review of carbon storage and sequestration values referring to U.S. cities is given by Nowak et al. (2013). The results which are suitable for comparison, are expressed as an average on a unit area basis $\left(\mathrm{kgm}^{-2}\right.$ canopy cover); the values of Boston, MA $\left(0.231 \mathrm{kgm}^{-2}\right)$, New York, NY $\left(0.230 \mathrm{kgm}^{-2}\right)$ and Atlanta, GA $\left(0.229 \mathrm{kgm}^{-2}\right)$, are very close to the average value for Szeged $\left(0.232 \mathrm{kgm}^{-2}\right)$.

The work of Nowak et al. (2006) is a similar study on air pollution removal in U.S. cities, with values given for canopy cover unit area $\left(\mathrm{gm}^{-2}\right)$. The total amount of removed pollutants in Szeged is $6.5 \mathrm{gm}^{-2}$ and the values of Charleston, WV $\left(6.7 \mathrm{gm}^{-2}\right)$ and Minneapolis, $\mathrm{MN}\left(6.2 \mathrm{gm}^{-2}\right)$ are close to it. From European studies, the results for Victoria (London) and Barcelona (10.9 $\mathrm{gm}^{-2}$ and $9.3 \mathrm{gm}^{-2}$ ) are much higher than those for Szeged, which is due to the fact that these are crowded capital cities. There are also some differences if we look at the amounts of different pollutants separately, e.g. in Barcelona, the share of $\mathrm{NO}_{2}$ is higher $(17.87 \%)$ than in Szeged (6.5\%), where PM10 and $\mathrm{O}_{3}$ represent almost $90 \%$ of the total amount of pollutants removed.

The economic value of carbon sequestration is not very high compared to some other services of urban tree stands. This was stated by other authors as well (Soares et al., 2012). The ecosystem service of carbon sequestration by trees in an average European city is small compared with the total greenhouse gas emissions, but it is considerably higher if we compare it with the emissions derived from the sectors that are directly managed by the city council (Baró et al., 2014).

Air pollution removal provides much greater returns in monetary value. The levels of air pollution have been shown to be statistically associated with health status in Szeged, and it has been demonstrated as well in the case of $\mathrm{O}_{3}$ and PM10 (Matyasovszky et al., 2011), which are the pollutants removed in the largest amounts in Szeged. It should be noted that the air pollution concentration dataset could be obtained from only one monitoring station in the city. The station is situated not far from the city centre, but not inside it, thus the concentration values do not refer exactly to the most polluted sites' values. The significance of this service is also very high because a small change in air quality parameters can result in a strong improvement in environmental status, which has particular importance in city centres.

The structural attributes of the tree alleys in the case studies are mainly the direct results of the species composition and management characteristics. The low values of canopy missing and dieback for the trees of József Attila avenue are a consequence mainly of the protection of the tree alley during infrastructure development projects in previous years. In comparison, in Petőfi Sándor avenue, huge parts of the crowns were cut off during infrastructure development activities, even for some of the remaining trees as well, and the building works caused a deterioration in tree condition, in terms of crown dieback in some parts of the stand. The low "leaf area:average DBH" ratio in the case of the Sophora japonica trees of Hajnóczy street (which is parallel to the low "leaf area:carbon storage" ratio, as observed in the service provision section) is a result of frequent pruning. It is needed because of the characteristic airy, loose crown structure of the species, which calls for such maintenance. This problem is even more serious on Hajnóczy street because of the nearby high buildings. The high values of crown dieback are caused by the dying of lower branches of the large trees, which get too low amount of light.

The reason of the lower air pollutant removal values in the $16-30 \mathrm{~cm}$ DBH category in the case of József Attila avenue is that most of the trees in this diameter class belong to the population of an oak species with a columnar appearance (Quercus robur "Fastigiata"). The lateral distribution of the crown of this species is much lower than in the case of other species, which results in very small leaf area values, even if there are no large missing or dead parts in the crown.

With the comparison of the stands under different management regimes, our aim was to provide some preliminary results for a problem that needs further studies. The legal protection status that we used to differentiate between the chosen street pairs does not always result in characteristic management differences. For safety reasons, pruning and other small maintenance activities are allowed for the protected stands too, and many of the non-protected stands are in very good condition. The amount and growth of biomass and leaf area of trees (consequently, the provision of services) in a given $\mathrm{DBH}$ class is strongly affected by the growth characteristics and tolerance of urban circumstances of different species, besides management-related interventions. Although the investigated stands are in a very similiar built environment, there are also slight differences in crown light exposure, which also affects the amount of leaf area. Therefore, the differences in service provision can not be explained only by management differences. These complex interactions need further, targeted investigations, where, besides further empirical studies, simulation-based calculations may also play an important role in differentiating the effects of the above-mentioned factors.

With the comparison of the two neighbouring streets, of which one was the location of a complete tree alley replacement some years ago, we wanted to show the effects of tree clearcuts during building public space development projects on the amount of ecosystem services. In the place of the non-protected stand (Gutenberg street), a new tree line was planted. But even from our results it is clear that old-growth trees provide climate- and air quality-related ecosystem services to a very great extent. The maintenance costs of old-growth trees are generally higher, but in McPherson's (2003) results, for example, it is clear that for many of the investigated species, the cost-benefit ratio increased drastically for the older trees but the economic value of services was still greater than the increased costs.

Besides the two services investigated in our study, there is also the case for the service of microclimate regulation (through shading and evapotranspiration), which might also be expressed in economic value (e.g., through energy savings in buildings). The homogeneous tree line of newly-planted small trees obviously can not regulate microclimate in the same way as the former large trees with huge leaf area. Such streets remain street canyons with extreme heat load in the summers for many years to come. And people can be emotionally bound to big trees that are present in a certain place for long time, which means that old-growth trees provide important cultural services (aesthetic value, sense of place). These observations suggest that complete tree alley changes are not advisable from an ecosystem service point of view. 
Meanwhile, it should be noted that the tree alley of Hajnóczi street consists mainly of Sophora japonica trees, with the management problems described previously (bad condition, frequent pruning). This type of tree alley was the previous one in Gutenberg street, which might have contributed to the decision to clearcut. This also shows that before planting trees of different species, it is worth investigating their general condition and service-providing capacity in the city. For such purposes, creating and maintaining a tree cadastre database and analyses of ecosystem services similar to the ones presented in this study, may be advisable in as many cities as possible. The characteristics of different species' populations, their life cycles, the services provided during this time, and the benefit-cost relationships can be monitored in the best way if all management activities are also registered on a per tree basis.

\section{Conclusions}

In this study, we carried out the first tree individual-based urban ecosystem service assessment in Central Eastern Europe, based on a large complete tree inventory. This was achieved with an adaptation of the i-Tree Eco model (developed in the U.S.), which is a targeted tool to evaluate climate- and air quality-related ecosystem services of urban trees. The adaptation process required meteorological data collected by the national meteorological service, and air pollution data, which is collected in a measurement system that is owned by the ministry and which is available to the public. This means that the adaptation process can definitely be carried out in other countries of the $\mathrm{CEE}$ region, with similar responsible institutions.

With the help of i-Tree model, the actual state of smaller tree stands or even huge urban forests can be assessed, and the effects of tree removal losses in different development scenarios can also be quantified. Besides these practical applications, several research questions can be investigated based on the i-Tree results (together with the baseline tree cadastre database). In our study, we pointed out that such analyses may help forming urban tree species selection policies. Management-related interventions (such as pruning, which can also be affected by the protection status) can result in a decline in service provision (due to biomass removal), but its exact quantification and differentiation from other relevant factors need further, focused investigations.

\section{Acknowledgements}

This research was realized in the frames of TÁMOP 4.2.4. A/2-11-1-2012-0001 "National Excellence Program Elaborating and operating an inland student and researcher personal support system". The project was subsidized by the European Union and co-financed by the European Social Fund. We thank Istuán Szentistványi (delegate in the general assembly of Szeged) for providing valuable information on the urban tree management of the city. We are thankful to $\mathrm{Al}$ Zelaya and colleagues of the USDA Forestry Service for their technical assistance during the model adaptation.

\section{References:}

ÁKK (2014): Main macroeconomic indicators [online]. Website of the Government Debt Management Agency Private Company Limited by Shares. [online] [cit. 06.07.2015]. Available at: http://beta.akk.hu/makrotabla en.ivy?public.lang=en-US
BARÓ, F., CHAPARRO, L., GÓMEZ-BAGGETHUN, E., LANGEMEYER, J., NOWAK, D. J., TERRADAS, J. (2014): Contribution of Ecosystem Services to Air Quality and Climate Change Mitigation Policies: The Case of Urban Forests in Barcelona, Spain. AMBIO, 43: 466-479.

BOLUND, P., HUNHAMMAR, S. (1999): Ecosystem services in urban areas. Ecological Economics, 29: 293-301.

CAO, X., ONISHI, A., CHEN, J., IMURA, H. (2010): Quantifying the cool island intensity of urban parks using ASTER and IKONOS data. Landscape and Urban Planning, 96(4): 224-231.

CHAPARRO, L., TERRADAS, J. (2009): Ecological Services of Urban Forest in Barcelona. Barcelona City Council, Barcelona, Spain.

CITY OF MELBOURNE (2012): Urban Forest Strategy Making a great city greener 2012-2032 [online]. Website of the city of Melbourne [online] [cit. 06.07.2015]. Available at: http://www.melbourne.vic.gov.au/ Sustainability/UrbanForest/Documents/Urban_Forest_ Strategy.pdf

DONOVAN, G. H., BUTRY, D. T. (2011): The effect of urban trees on the rental price of single-family homes in Portland, Oregon. Urban Forestry and Urban Greening, 10(3): 163-168

ÉGERHÁZI, L. A., KOVÁCS, A., UNGER, J. (2013): Application of microclimate modelling and onsite survey in planning practice related to an urban micro environment. Advances in Meteorology, Article ID: 251586 .

GIERGICZNY, M., KRONENBERG, J. (2014): From Valuation to Governance: Using Choice Experiment to Value Street Trees. AMBIO, 43(4): 492-501.

GÓMEZ-BAGGETHUN， E., BARTON， D. N. (2013): Classifying and valuing ecosystem services for urban planning. Ecological Economics, 86: 235-245.

GÓMEZ-BAGGETHUN, E., GREN, A., BARTON, D.N., LANGEMEYER, J., MCPHEARSON, T., O'FARRELL, P., ANDERSSON, E., HAMSTEAD, Z., KREMER, P. (2013): Urban Ecosystem Services. In: Elmqvist, T. et al. [eds.]: Urbanization, Biodiversity and Ecosystem Services: Challenges and Opportunities (pp. 175-251). Springer.

HAASE, D., LARONDELLE, N., ANDERSSON, E., ARTMANN, M., BORGSTRÖM, S., BREUSTE, J., GÓMEZ-BAGGETHUN, E., GREN, A., HAMSTEAD, Z., HANSEN, R., KABISCH, N., KREMER, P., LANGEMEYER, J., RALL, E. L., MCPHEARSON, T., PAULEIT, S., QURESHI, S., SCHWARZ, N., VOIGT, A., WURSTER, D., ELMQVIST, T. (2014): A Quantitative Review of Urban Ecosystem Service Assessments: Concepts, Medels and Implementation. AMBIO, 43(4): 413-433.

I-TREE (2014): i-Tree Eco User Manual v5.0. [online] [cit. 06.07.2015]. Available at: http://www.itreetools.org/ resources/manuals/Eco_Manual_v5.pdf

JIM, C. Y., CHEN, W. Y. (2014): Assessing the ecosystem service of air pollutant removal by urban trees in Guangzhou (China). Journal of Environmental Management, 88(4): 665-676. 
KÁNTOR, N., ÉGERHÁZI, L. A., UNGER, J. (2012): Subjective estimations of thermal environment in recreational urban spaces - Part 1: investigations in Szeged, Hungary, International Journal of Biometeorology, 56(6): 1075-1088.

KIRNBAUER, M. C., BAETZB, B. W., KENNEYC, W. A. (2013): Estimating the stormwater attenuation benefits derived from planting four monoculture species of deciduous trees on vacant and underutilized urban land parcels. Urban Forestry and Urban Greening, 12(3): 401-407.

LEE, H., HOLST, J., MAYER, H. (2013): Modification of Human-Biometeorologically Significant Radiant Flux Densities by Shading as Local Method to Mitigate Heat Stress in Summer within Urban Street Canyons. Advances in Meteorology, Article ID: 312572.

LEHMANN, I., MATHEYA, J., RÖßLER, S., BRÄUER, A., GOLDBERG, V. (2014): Urban vegetation structure types as a methodological approach for identifying ecosystem services - Application to the analysis of micro-climatic effects. Ecological Indicators, 42: 58-72.

LIU, C. F., HE, X. Y., CHEN, W., ZHAO, G. L., LI, L., XU, W. D. (2008): Ecological benefit evaluation of urban forests in Shenyang City based on QuickBird image and CITYgreen model. 19(9): 1865-1870.

MAKRA, L. (2005): The role of traffic in modifying air quality in a medium-sized city, Szeged, Hungary. Epidemiology, 16(5): S62.

MARTIN, N. A., CHAPPELKA, A. H., LOEWENSTEIN, E. F., KEEVER, G. J. (2012): Comparison of carbon storage, carbon sequestration, and air pollution removal by protected and maintained urban forests in Alabama, USA. International Journal of Biodiversity Science, Ecosystem Services and Management, 8(3): 265-272.

MATYASOVSZKY, I., MAKRA, L., BÁLINT, B., GUBA, Z., SÜMEGHY, Z. (2011): Multivariate analysis of respiratory problems and their connection with meteorological parameters and the main biological and chemical air pollutants. Atmospheric Environment, 45(25): 4152-4159.

MCPHERSON, E. G. (2003): A benefit-cost analysis of ten street tree species in Modesto, California, U.S. Journal of Arboriculture, 29(1): 1-8.

MCPHERSON, E. G., KENDALL, A. (2014): A life cycle carbon dioxide inventory of the Million Trees Los Angeles program. International Journal of Life Cycle Assessment, 19(9): 1653-1665.

MEA (2005): Millennium Ecosystem Assessment: Ecosystems and Human Well-being -Synthesis. Island Press, Washington, DC.

NOWAK, D. J., CRANE, D. E., STEVENS, J. C. (2006): Air pollution removal by urban trees and shrubs in the United States. Urban Forestry and Urban Greening, 4(3): 115-123

NOWAK, D. J., CRANE, D. E., STEVENS, J. C., HOEHN, R. E., WALTON, J.T., BOND, J. (2008): A Ground-Based Method of Assessing Urban Forest Structure and Ecosystem Services. Arboriculture and Urban Forestry, 34(6): 347-358.

NOWAK, D. J., GREENFIELD, E. J., HOEHN, R. E., LAPOINT, E. (2013): Carbon storage and sequestration by trees in urban and community areas of the United States. Environmental Pollution, 178: 229-236.
NOWAK, D. J., HIRABAYASHI, S., BODINE, A., GREENFIELD, E. (2014): Tree and forest effects on air quality and human health in the United States. Environmental Pollution, 193: 119-129.

O'CAMPO, P., SALMON, C., BURKE, J. (2009): Neighbourhoods and mental well-being: What are the pathways? Health and Place, 15(1): 56-68.

PENG, L., CHEN, S., LIU, Y., WANG, J. (2008): Application of CITYgreen model in benefit assessment of Nanjing urban green space in carbon fixation and runoff reduction. Frontiers of Forestry in China, 3(2): 177-182.

PERRINGS, C., DURAIAPPAH, A., LARIGAUDERIE, A., MOONEY, H. (2011): The Biodiversity and Ecosystem Services Science-Policy Interface. Science, 331(6021): 1139-1140.

PETZ, K., VAN OUDENHOVEN, A. P. E. (2012): Modelling land management effect on ecosystem functions and services: a study in the Netherlands. International Journal of Biodiversity Science, Ecosystem Services and Management, 8(1-2): 135-155.

POTHIER, A. J., MILLWARD, A. A. (2013): Valuing trees on city-centre institutional land: an opportunity forurban forest management. Journal of Environmental Planning and Management, 56(9): 1380-1402.

POWERCONSULT (2010): A villamosenergia termelés externális költségei, különös tekintettel a megújuló energiaforrásokra [online]. Website of the Hungarian Energy and Public Utility Regulatory Authority. [cit. 06.07.2015]. Available at: http://www.mekh.hu/ gcpdocs/201006/meh_externalia_powerconsult.pdf

ROGERS, K., JALUZOT, A., NEILAN, C. (2012): Green Benefits in Victoria Business Improvement District [online]. London Climate Change website [cit. 06.07.2015.]. Available at: http://climatelondon. org.uk/wp-content/uploads/2013/03/Green-Benefits-inVictoria-Business-Improvement-District.pdf

ROGERS, K., JARRATT, T., HANSFORD, D. (2011): Torbay's Urban Forest - Assessing Urban Forest Effects and Values [online]. Torbay Council website [cit. 06.07.2015.]. Available at: http://www.torbay.gov.uk/tuf.pdf

RUSSO, A., ESCOBEDO, F. J., TIMILSINA, N., SCHMITT, A. O., VARELA, S., ZERBE, S. (2014): Assessing urban tree carbon storage and sequestration in Bolzano, Italy. International Journal of Biodiversity Science, Ecosystem Services and Management, 10(1): 54-70.

SANDER, H., POLASKY, S., HAIGHT, R. G. (2010): The value of urban tree cover: A hedonic property price model in Ramsey and Dakota Counties, Minnesota, USA. Ecological Economics, 69(8): 1646-1656.

SOARES, A. L., REGO, F. C., MCPHERSON, E. G., SIMPSON, J. R., PEPER, P. J., XIAO, Q. (2011): Benefits and costs of street trees in Lisbon, Portugal. Urban Forestry and Urban Greening, 10(2): 69-78.

SZATMÁRI, J. (2005): Szélerózió-veszélyeztetettség értékelése a Duna-Tisza-közén RWEQ modell alkalmazásával (Evaluation of Wind Erosion Risk on the Danube-Tisza Interfluve using the Revised Wind Erosion Equation (RWEQ) [in Hungarian]). Paper presented at the II. Hungarian Geographical Conference, Szeged, 2-4.09.2004. [online]. [cit.06.07.2015]. Available at: http://geography. hu/mfk2004/mfk2004/cikkek/szatmari_jozsef.pdf 
TEEB (2010a): The Economics of Ecosystems and Biodiversity: Mainstreaming the Economics of Nature: A synthesis of the approach, conclusions and recommendations of TEEB. Earthscan, London-Washington.

TEEB (2010b): The Economics of Ecosystems and Biodiversity: Mainstreaming the Economics of Nature: Ecological and Economic Foundations. ed. by P. Kumar, Earthscan, London-Washington.

TEKNOMO, K. (2005): Public park valuation using travel cost method. Proceedings of the Eastern Asia Society for Transportation Studies, 5: 1249-1264.

TOL, R.S. J. (2008): The Social Cost of Carbon: Trends, Outliers and Catastrophes. Economics: The OpenAccess, Open-Assessment E-Journal, 2 (2008-25). [cit.06.07.2015]. Available at: http://dx.doi.org/10.5018/ economics-ejournal.ja.2008-25
TYRVÄINEN, L., SILVENNOINEN, H., KOLEHMAINEN, O. (2003): Ecological and aesthetic values in urban forest management. Urban Forestry and Urban Greening, 1(3): 135-149.

UNGER, J., LELOVICS, E., GÁL, T. (2014): Local Climate Zone mapping using GIS methods in Szeged. Hungarian Geographical Bulletin, 63(1): 29-41.

WÄLCHLI, G. (2012): Ökosystemdienstleistungen als ökonomische Strategie? i-Tree: ein Instrument für die Wertermittlung von Stadtbäumen Zusammenfassung [dissertation - in German]. Wädenswil: Zürcher Hochschule für Angewandte Wissenschaften.

Initial submission 8 December 2014, final acceptance 26 June 2015

\section{Please cite this article as:}

KISS, M., TAKÁCS, Á., POGÁCSÁS, R., GULYÁS, Á. (2015): The role of ecosystem services in climate and air quality in urban areas: Evaluating carbon sequestration and air pollution removal by street and park trees in Szeged (Hungary). Moravian Geographical Reports, 23(3):36-46. DOI: 10.1515/mgr-2015-0016. 